\title{
ISLAMIC BOARDING SCHOOL-BASED STRATEGY IN ARABIC TEACHING AND LEARNING OF MUSLIM MINORITY WEST PAPUA
}

\author{
Ismail Suardi Wekke*, Nurhayati*, Miftah Farid** \\ State Islamic College (STAIN) Sorong, West Papua \\ **State Islamic University of Sunan Gunung Djati, Bandung \\ Email: iswekke@gmail.com
}

Paper Presented in

The International Conference Arabic Language Education and Literature and Islamic Values between Expectation and Realization

Bandung, 11-12 November 2016

\begin{abstract}
Arabic language becomes important and compulsive to understand Quran in schools and madrasah (Islamic school) which have students as learning target. In addition, learning is not only about clasroom. The exploration could be extend to environment where the students live around. Therefore, this article would identify the process of Arabic learning and teaching in Islamic boarding school-based strategy. To enhance the process of learning in the madrasah (school), the management provide boarding or domitory facilities for student who can not reach the school every day. This reserach was conducted in West Papua of Indonesia. The research is a series of research to identify the muslim minority Arabic teaching and learning in the island of Papua. Non-participant observation and in-depth interview were employed in collecting data. This article shows that there are four programs were implemented to accelerate students' competencies in acquitting the target language. Furthermore, this article discusses the issue of strategy was inspired by the development of technology and knowledge as well as the globalization putting the teacher not to be the only one source, likewise the school. On the other hand, print and electronic media, internet and life around the students can be taken as learning sources. Secondly, strategy which is giving chances to the learners to play as dominants in learning management. Finally, this article recomends further research in exploration the topic to extend the potential development of Arabic teaching and learning the region of muslim minority.
\end{abstract}

Keywords: learning model, strategy, boarding school-based

\section{INTRODUCTION}

Learning Arabic language in school is a tool to support school's facilities and infrastructure. Arabic learning, in Indonesia, has been started since the growth of Islam in Indonesia. This fact shows that Arabic Language in Indonesia had played important role for Indonesian culture and people before other foreign languages. For Indonesian Muslims, Arabic language is known as language used for the Holy Quran, communication and information. In the religious viewpoint, it is positioned as language of worship of all Muslims in the world. 
There are four basic competencies should be mastered by the learners are (1) Mahârah Istima, (2) Mahârah Kalam, (3) Maharah Qiraah dan (4) Maharah Kitabah. The fourth skills should be taught within various functions and contexts, so that various approaches, methods, techniques, strategies and learning media to use Arabic Language as media of orientalism and capitalism interests. Hence, these should be developed through its teaching methods and studies of various aspects like approaches, strategies, models, technology, media, evaluation, management, curriculum and methods in several model of educational unit (Agerström \& Rooth, 2009; Contessi, 2015; Whipple \& Russell, 2007).

Learning strategy in question includes natures of scope and sequence of activities from Islamic boarding school, kindergarten to formal school. Arabic language is a compulsory subject in Islamic school or madrasah. It becomes important factor for students or learners to master Arabic language in the institutions, especially for scientific review referring to Quran and hadith. To support them to understand Islamic scientific review, Arabic skill is needed (Wekke, 2016). Therefore, the compulsive thing for institutions having learners aged 17 years is the implementation of learning process using andragogy approach. To make adults easy to review Islamic sciences needs appropriated approach in Arabic learning since educational level of them is different from it of children. On the other hand, in Adult Cognition as a Dimension of Lifelong Learning assumed that adults' learning is just expression (Sebastian, 2015).

Some arguments in his book - Leaning Model: Creating Creative and Effective Teaching and Learning Processes, are as follows: Learning strategy can be defined as each selected activity which can provide facilities or helps for learners to achieve the goals of particular subject (Bannan-Ritland, 2003). Learning strategy is series of ways selected to deliver leaning methods in particular learning environment. The mentioned learning strategy includes properties of scope. It is not limited on procedures and stages of learning process, 
but from its definition above, it was clearly mentioned that learning strategy should contain explanation about methods/procedures and techniques used during the learning process (Maldonado, Khan, Moon, \& Rho, 2011).

\section{LEARNING STRATEGY}

Learning strategy has a broader definition than the methods and techniques. It means that learning methods/procedures and techniques are parts of learning strategy. Learning Model-Oriented Learning Strategy Creates Creative and Effective Learning and Teaching Processes. Kinds of Learning Strategy can be divided to two groups: (1) exposition-discovery learning and (2) group-individual learning. Exposition strategy is a strategy where learning materials are presented to the students in finished forms requiring them to master such materials. It is also called direct learning strategy since materials is directly presented the students. Then, they are required to process and master all materials in full. Meanwhile, discovery strategy means that learning materials should be searched and found by the students themselves through various activities, while the teachers mostly act as facilitators and guiders. Due to these properties, the latter strategy is often called indirect strategy.

Self-learning strategy means that both materials and ways of learning are designed for self-learning activities. Speed, slowness and success of students' learning are significantly determined by the students themselves. Meanwhile, learning in groups is done in teams. Students group is taught by one or several teachers. The learning process may be done in a big group or classically or in small groups. Whereas Education Process Standards-Oriented Learning Strategy includes setting of materials and program packages should be delivered to the students (Borko, 2004).

Eventually, to find it developed and advanced, it must by exploring comprehensive concepts regarding useful and applicable learning strategy in learning activities. An aspect 
determining the success of learning process is learning strategy used. In line with the professionalism, teachers should be able to select and use strategy which is appropriate with the goals set. There are strategies can be selected by teachers for language learning process to improve students' achievement relating to lingual skills.

Teachers are recommended to use various learning strategies giving the students various learning experiences. There are many ways to see varieties of learning strategy. Such diversities are generally in line with the width of learning domain, from the planning of the goals and the ways used to achieve, then the implementation of steps and methods, as well as the ways to measure goals achievement (Ellis, Jarkey, Mahony, Peat, \& Sheely, 2007). In addition, management of class is also supporting the goals achievement. From the learning approach viewpoint, Arabic learning system can be classified into humanistic, technological and analytical approaches. According to the emphasis on the main learning components, the main components are teacher, learner and learning materials. Therefore, a learning strategy can be seen from these three components. There is learning strategy which focuses on the teachers. It is the older strategy named traditional strategy. A teacher is considered as the most dominant information source. He/she is active and dominating times, otherwise the students are passive.

A learning strategy focusing on the learners is referring to a view seeing that teaching is creating atmosphere of where the students may do their learning process optimally. The main focus in this strategy is the students who are emphasized on their ability to find, process, understand and use information they get. Meanwhile, a learning strategy focusing on learning materials is usually sourced from school's official textbooks or it can be from environment and real life. As for the strategy focusing on learning materials is using nonanalytic, communicative, audio-lingual, and cognitive approaches (Holm, Olla, Moura, \& Warhaut, 2006; Izfanna \& Hisyam, 2012; Whipple \& Russell, 2007; Zetie, 2002). 
Viewed from Arabic language techniques, Arabic language strategies including techniques of teaching lingual aspects (techniques of reading and writing teaching, techniques of grammar teaching and verbs), and techniques of language skills teaching (techniques to teach listening, speaking, reading and writing). Since learning strategy is closely related to the learning process, it is suggested for classification of learning strategy based on standardized process in the learning process (Van Bruggen, 2005). From the four classified, it can be understood that the learning strategies are based on learning components emphasized on, learning materials management and leaning materials management direction. Kinds of learning strategies based on their classification can be explained as follows: Strategy based on the main components that are teacher, learner and learning materials. Hence, learning strategy can be seen from the three components. There is learning strategy which focuses on the teachers and there is another focusing on the students. The strategy which focuses on the teachers is the older strategy named traditional strategy (Wekke, 2015). A teacher is considered as the most dominant information source. He/she is active and dominating times, otherwise the students are passive. He/she is active and dominating times, otherwise the students are passive. A learning strategy focusing on the learners is referring to a view seeing that teaching is creating atmosphere of where the students may do their learning process optimally. The main focus in this strategy is the students who are emphasized on their ability to find, process, understand and use information they get. Meanwhile, a learning strategy focusing on learning materials is usually sourced from school's official textbooks or it can be from environment and real life (Ellis et al., 2007).

This strategy is inspired by the development of technology and knowledge as well as the globalization putting the teacher not to be the only one source, likewise the school. On the other hand, print, electronic and internet media, as well as environment around the students can be taken as sources of learning process. Strategy which is focusing on teacher has been 
developed as expository learning and deductive learning model. Meanwhile, the strategy focusing on the learners has been developed into discovery, inquiry, cooperative and inductive learning models. As for strategy focusing on the materials is a learning model which is based on problems should be discussed and solved together. Based on material management process, learning process is always engaging maximally three main elements are teacher, learner and subject material.

Subject materials become references of both learners and teachers. Teachers are referring to the materials to organize, represent and develop particular learning activities. Meanwhile students take them as references to understand and master subject they review. Based on management of subject material and lesson, strategies can be divided as two: first, strategy emphasizing on material delivering process verbally by the teacher to the students. Secondly, strategy giving chances to the learners to play as dominants in managing learning process based on emphasis on learning components. Based on the process of subject material management, there are two models developing, are expository and heuristic learning models. Expository learning model is emphasizing on verbal material delivering process by the teacher to group of students that is intended to make the students master the materials optimally (Durugbo, 2014). Learning strategy which is focusing on learning materials is usually sourced from school's official textbooks or it can be from environment and real life (Wekke \& Andriansyah 2016).

\section{CONLUSION}

This classification is inseparable from learning strategies differentiation based on emphasis on learning components. Based on the process of subject material management, there are two developing learning models are expository and heuristic models. Expository learning model is a model emphasizing on managing materials completely before delivering 
in front of the class to let the students understand. This strategy is inspired by the development of technology and knowledge as well as the globalization putting the teacher not to be the only one source, likewise the school. On the other hand, print, electronic and internet media, as well as environment around the students can be taken as sources of learning process. Strategy which is focusing on teacher has been developed as expository learning and deductive learning model. Meanwhile, the strategy focusing on the learners has been developed into discovery, inquiry, cooperative and inductive learning models.

\section{REFERENCE}

Agerström, J., \& Rooth, D.-O. (2009). Implicit prejudice and ethnic minorities: ArabMuslims in Sweden. International Journal of Manpower, 30(1/2), 43-55.

Bannan-Ritland, B. (2003). The Role of Design in Research: The Integrative Learning Design Framework. Educational Researcher.

Borko, H. (2004). Professional Development and Teacher Learning: Mapping the Terrain. Educational Researcher.

Contessi, N. P. (2015). Central Asia in Asia: Charting growing trans-regional linkages. Journal of Eurasian Studies, 7(1), 3-13.

Durugbo, C. (2014). Managing information for collaborative networks. Industrial Management \& Data Systems, 114(8), 1207-1228.

Ellis, R. a., Jarkey, N., Mahony, M. J., Peat, M., \& Sheely, S. (2007). Managing quality improvement of eLearning in a large, campus-based university. Quality Assurance in Education, 15(1), 9-23.

Holm, J., Olla, P., Moura, D., \& Warhaut, M. (2006). Creating architectural approaches to knowledge management: an example from the space industry. Journal of Knowledge Management, 10(2), 36-51.

Izfanna, D., \& Hisyam, N. A. (2012). A comprehensive approach in developing akhlaq. Multicultural Education \& Technology Journal, 6(2), 77-86.

Maldonado, U. P. T., Khan, G. F., Moon, J., \& Rho, J. J. (2011). E-learning motivation and educational portal acceptance in developing countries. Online Information Review, 35(1), 66-85.

Sebastian, C. L. (2015). Social cognition in adolescence: Social rejection and theory of mind. Psicología Educativa, 21(2), 125-131.

Van Bruggen, J. (2005). Theory and practice of online learning. British Journal of Educational Technology, 36(1), 111-112.

Wekke, I. S. (2015). Antara tradisionalisme dan kemodernan : pembelajaran bahasa Arab di minoritas muslim Papua Barat. Jurnal Peradaban Islam Tsaqafah, Vol. 11(2), 313-332.

Wekke, I. S. (2016). Pembelajaran Bahasa Arab di Madrasah. Yogyakarta: Deepublish.

Wekke, Ismail Suardi \& Andriansyah. (2016). From Gontor to Sorong: muslim minority practices on Arabic teaching and learning" in Sosiohumanika: Jurnal Pendidikan Sains Sosial dan Kemanusiaan, Vol.9(1) Mei, 49-54.

Whipple, J. M., \& Russell, D. (2007). Building supply chain collaboration: a typology of 
collaborative approaches. The International Journal of Logistics Management, 18(2), 174-196.

Zetie, S. (2002). The quality circle approach to knowledge management. Managerial Auditing Journal, 17(6), 317-321. 